\title{
PILOT FRUIT DRIER FOR LOS AZUFRES GEOTHERMAL FIELD \\ MICHOACAN, MEXICO
}

FEBRUARY 1993

DUE/ID/13040--19

DE93 008560

\section{DISCLAIMER}

This report was prepared as an account of work sponsored by an agency of the United States Government. Neither the United States Government nor any agency thereof, nor any of their employees, makes any warranty, express or implied, or assumes any legal liability or responsibility for the accuracy, completeness, or usefulness of any information, apparatus, product, or process disclosed, or represents that its use would not infringe privately owned rights. Reference herein to any specific commercial product, process, or service by trade name, trademark, manufacturer, or otherwise does not necessarily constitute or imply its endorsement, recommindation, or favoring by the United States Government or any agency thereof. The views and opinions of authors expressed herein do not necessarily state or reflect those of the United States Government or any agency thereof.

Worí Performed Under Grant No. DE-FG07-901D13040

For

U. S. Department of Energy

Office of Industrial Technologies

Washington, D.C.

By

Geo-Heat Center

Oregon Institute of Technology

Klamath Falls, OR 97601

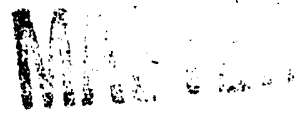




\section{PILOT FRUIT DRIER \\ for \\ Los Azufres Geothermal Field \\ Michoacan, Mexico}




\title{
PILOT FRUIT DRIER \\ For \\ Los Azufres Geothermal Field Michoacan, Mexico
}

\author{
Prepared For: \\ Gerencia de Proyectos Geothermoelectrios \\ Comision Federal de Electricidad \\ Morelia, Michoacan, Mexico \\ Prepared By: \\ John W. Lund, P.E. \\ Geo-Heat Center \\ oregon Institute of Technology \\ 3201 Campus Drive \\ Klamath Falls, OR 97601
}




\section{DISCLAIMER STATEMENT}

This report was prepared with the support of the U.S. Department of Energy (DOE Grant No. DE-FG07-90ID 13040). However, any opinions, findings, conclusions, or recommendations expressed herein are those of the author(s) and do not necessarily reflect the view of DOE. 


\section{TABLE OF CONTENTS}

Introduction $\ldots \ldots \ldots \ldots \ldots \ldots \ldots \ldots \ldots \ldots \ldots \ldots \ldots \ldots \ldots \ldots \ldots \ldots$

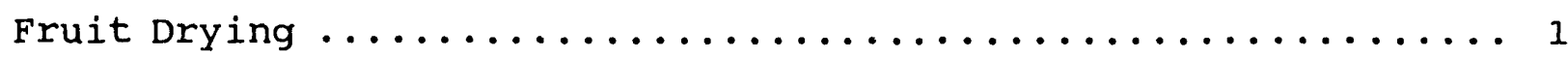

Drying Tray Design .........................

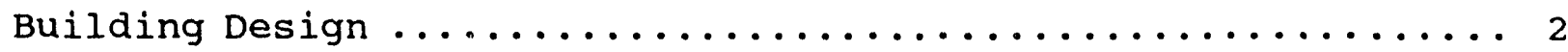

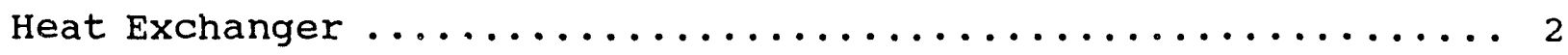

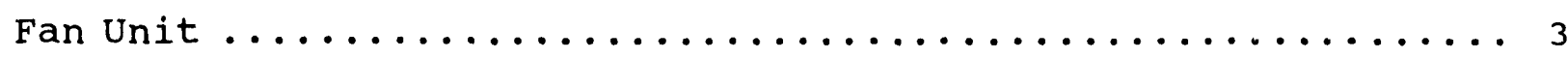

Construction and operation $\ldots \ldots \ldots \ldots \ldots \ldots \ldots \ldots \ldots \ldots \ldots \ldots \ldots \ldots \ldots \ldots$

Appendix:

Building and Tray Design Drawings

Fan and Heat Exchanger Design for Pace Engineered Sales

Drying Fruit at the Los Azufres Geothermal Field

Letter by James Thompson

Fruit Dehydration (Bulletin 698) 


\section{Introduction}

Comision Federal de Electricidad (CFE) has a Division in charge of the exploration of a geothermal reservoir located in Los Azufres, state of Michoacan. At present, CFE is only using the steam of the wells and rejecting the hot water that comes off associated with the steam.

CFE is interested in promoting the use of the hot water in industries with high consumption of heat. So far, they have installed a chamber for drying lumber (wood) with very good results. Several local industries are interested in constructing facilities at Los Azufres and to buy the heat from CFE. They have constructed a greenhouse to grow flowers in winter and produce gladiolus bulbs.

Since the region of Los Azufres is mainly a fruit producer (peaches, pears, apples, guava, etc.), they propose to install a small "fruit drier" for demonstration purpose. They are confident that if they succeed in showing the feasibility of drying fruit with geothermal water, they will have a demand for larger drying installations.

Based on a trip to the Los Azufres geothermal field in December of 1992, a design for a pilot geothermal fruit drier was undertaken for $G F E$. The details of the geothermal field and the local fruit production are detailed in an attached report prepared by Engineer Miguel Rangel.

\section{Fruit Drying}

The fruit in the area is mainly pears. Thus, the drier was designed for this purpose; however, other fruits can also be dried in the same drier.

The processing and preparation of the fruit is based on a 1946 report prepared by the California Agricultural Experiment station (Bulletin 698). No new publications are available; however, the information is still valid accordiny to Dr. James Thompson of the Agricultural Engineering Station at U.C. Davis. A copy of Bulletin 698 is available in the Geo-Heat Center library.

\section{Drying Tray Design}

Two trucks will be used; each $100 \mathrm{~cm} \times 100 \mathrm{~cm}$ by $182 \mathrm{~cm}$ high when loaded with trays. The truck will have a base with four casters (pivot wheels) and a detachable handle that can be attached at either end. This will allow the trucks to be reversed when halfway through the drying process time. The base will be of plywood approximately $2 \mathrm{~cm}$ thick. The trucks will each carry 30 trays. 
The trays will be constructed of $1 \mathrm{~cm}$ thick plywood and have a $5 \mathrm{~cm}$ high by $2 \mathrm{~cm}$ wide wood strip attached to either edge. The plywood will have $1 \mathrm{~cm}$ diameter holes drilled in them for drainage.

The trays are each designed to carry approximately $13.5 \mathrm{~kg}$ of moist fruit, or approximately $800 \mathrm{~kg}$ total for the 60 trays on two trucks. These weights will vary, depending on the type of fruit and placement on the trays.

\section{Building Design}

The drier building will be about $400 \mathrm{~cm}$ long, $135 \mathrm{~cm}$ wide and 320 $\mathrm{cm}$ high. The actual dimensions will depend upon the size of local building materials.

The walls will be constructed of concrete block, the ceiling and roof of timber and the floor of placed concrete. The floor will have a slight depression down the middle and slope towards the front doors for ease of cleaning. The fan motor will be housed on the roof away from the hot air stream.

The trucks and walls will be designed so that there is about 2 to $21 / 2 \mathrm{~cm}$ of clearance on either side and at the top.

Louvered doors will be provided for entering, recirculation and leaving air. The louvers will be manually set, but could be set automatically as controlled by temperature sensors.

\section{Heat Exchanger}

The required air flow for fruit drying is about $152 \mathrm{~m} / \mathrm{min}$ (500 $\mathrm{ft} / \mathrm{min})$. Assuming the trays and fruit block $70 \%$ of the tunnel, then the cross section for air flow will be $1 \mathrm{~m} \times 2 \mathrm{~m} \times 0.30=0.6$ $\mathrm{m}^{2}$. Thus, a capacity of $90 \mathrm{~m}^{3} / \mathrm{min}\left(2700 \mathrm{ft}^{3} / \mathrm{min}\right)$ will be needed. Converting this requirement to $3000 \mathrm{~m}(10,000 \mathrm{ft})$ elevation, a capacity of $120 \mathrm{~m}^{3} / \mathrm{min}\left(4500 \mathrm{ft}^{3} / \mathrm{min}\right)$ will be necessary at Los Azufres.

A minimum $0^{\circ} \mathrm{C}\left(32^{\circ} \mathrm{F}\right)$ outside entering air temperature and a $71^{\circ} \mathrm{C}$ $\left(160^{\circ} \mathrm{F}\right)$ drying temperature was assumed. The geothermal resource was assumed to enter at $121^{\circ} \mathrm{C}\left(250^{\circ} \mathrm{F}\right)$ and exit at $99^{\circ} \mathrm{C}\left(210^{\circ} \mathrm{F}\right)$. Based on these assumptions, the required heat exchanger will need two rows of 8 tubes at $91 \times 91 \mathrm{~cm}(36 \times 36$ in) cross sections.

The geothermal flow rate can be adjusted by a valve to compensate for changing outside air temperature. A three-way valve with a temperature sensor could be used for automatic control. 
The coil model number from Pace is: $82 \mathrm{HW}-36.0 \times 36.0-\mathrm{A}-6 / 8$. The estimated price is $\$ 800$; however, it can probably be purchased for less.

\section{Fan Unit}

The tube axial fan was designed for $120 \mathrm{~m}^{3} / \mathrm{min}\left(4500 \mathrm{ft}^{3} / \mathrm{min}\right)$ and $2 \mathrm{~cm}(3 / 4$ inch) of water pressure loss (air flow friction loss). This will require 1.05 BHP or a $1.5 \mathrm{hp}$ motor. The fan will be 45 $\mathrm{cm}$ (18 inches) in diameter and have 5 blades with a $10.5^{\circ}$ blade tip pitch. Due to the high temperature of the air flow, the fan motor will have to be located on top of the building outside of the air stream. Details of the fan and housing are on the attached diagram.

The estimated cost is $\$ 1650$, but this again is probably hj.gn. The fan specification from Pace is: 18D-6H-5RII-10.5T.

\section{Construction and operation}

It is estimated that this unit will be constructed with local materials during the spring of 1993. Operation will begin for the Summer/Fall 1993 harvest season.

The actual temperature and air flow rates will have to be adjusted by trial-and-error to achieve the proper final product in terms of moisture and color. 
APPENDIX 

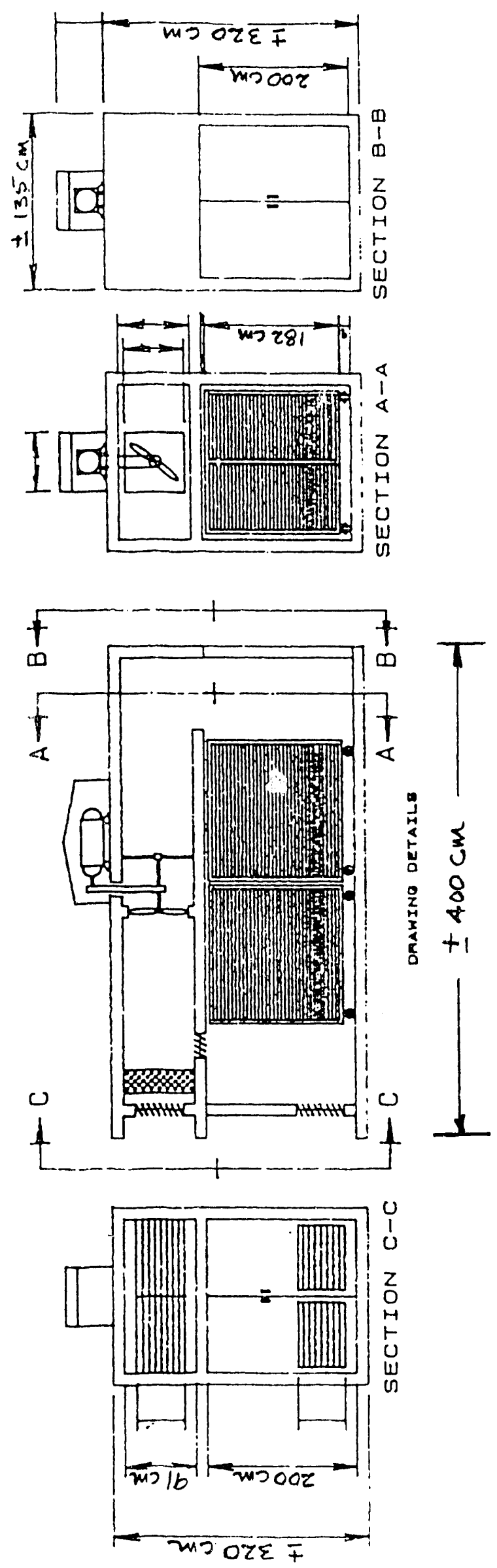

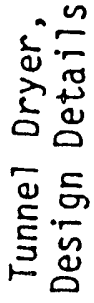

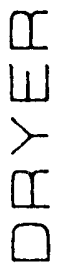

\begin{tabular}{l}
1 \\
$Z$ \\
$Z$ \\
\hline
\end{tabular} 


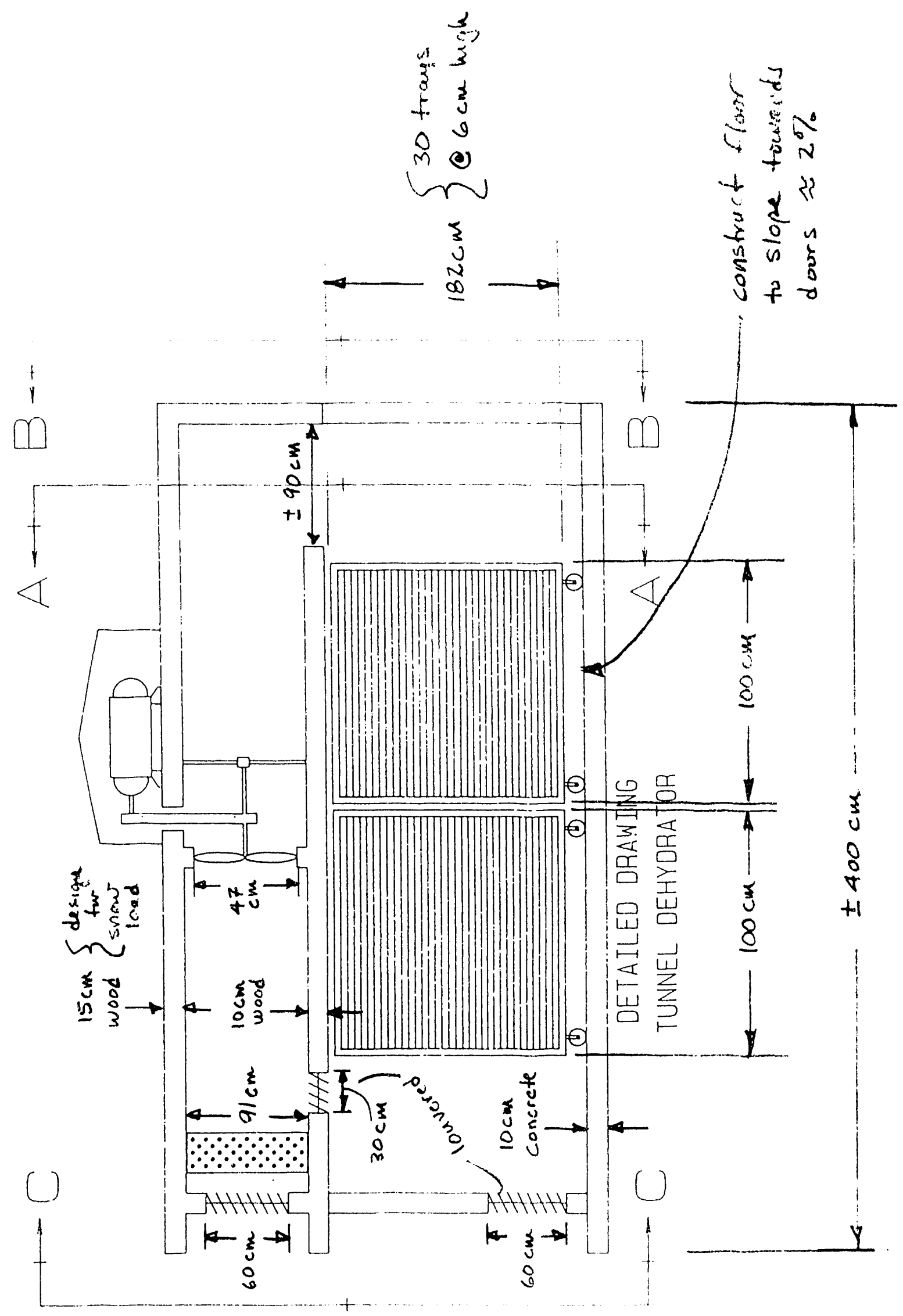




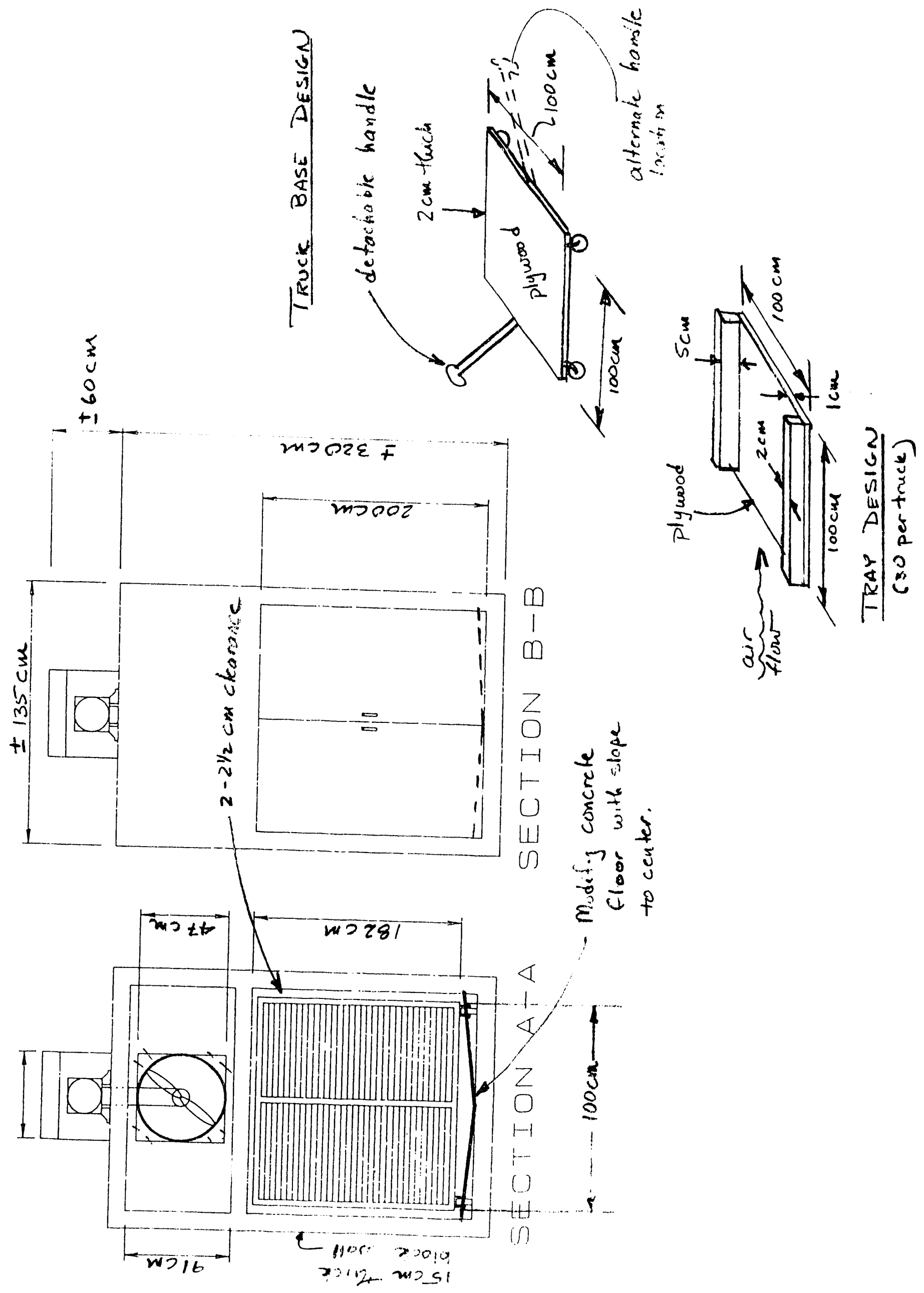




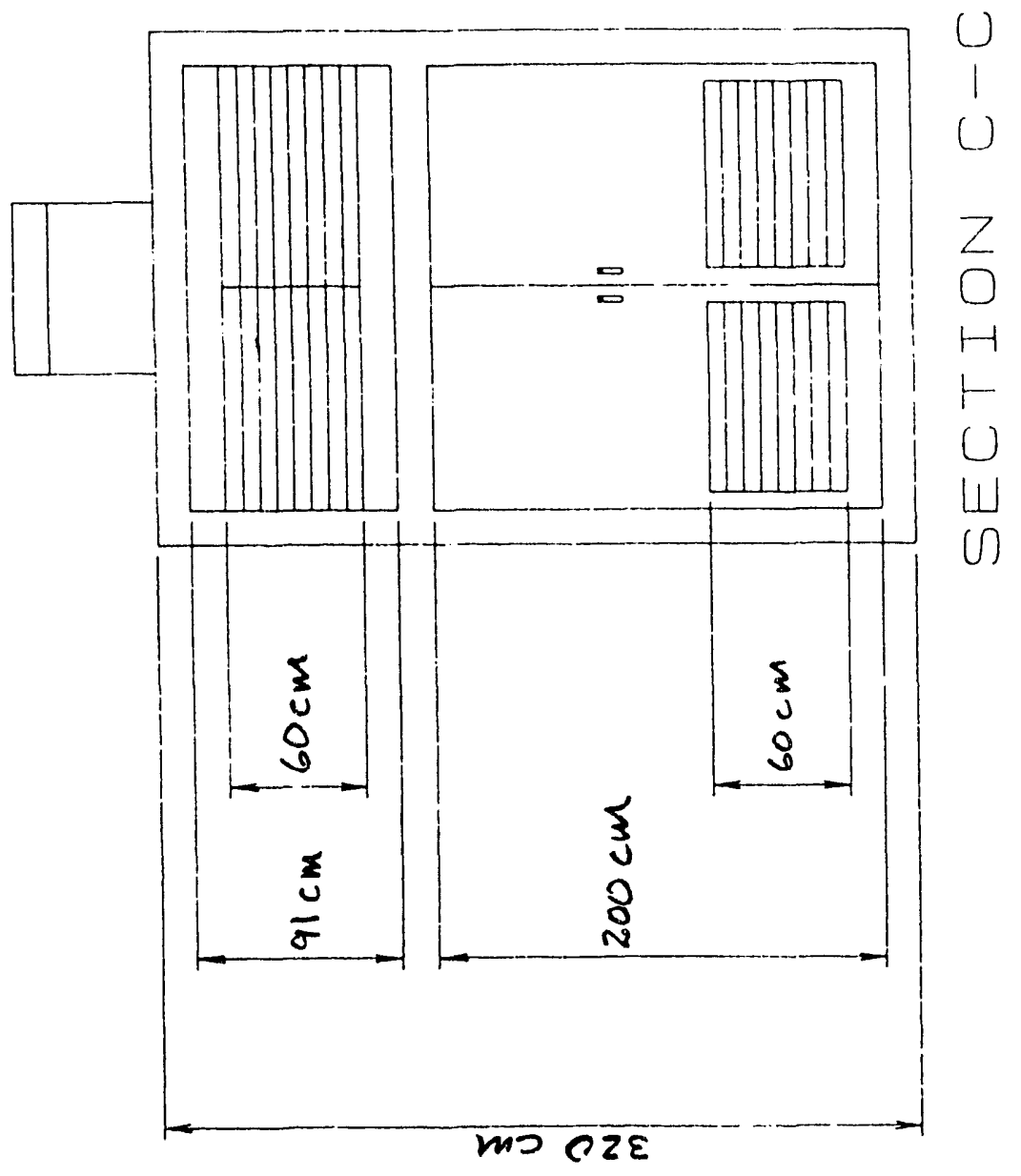




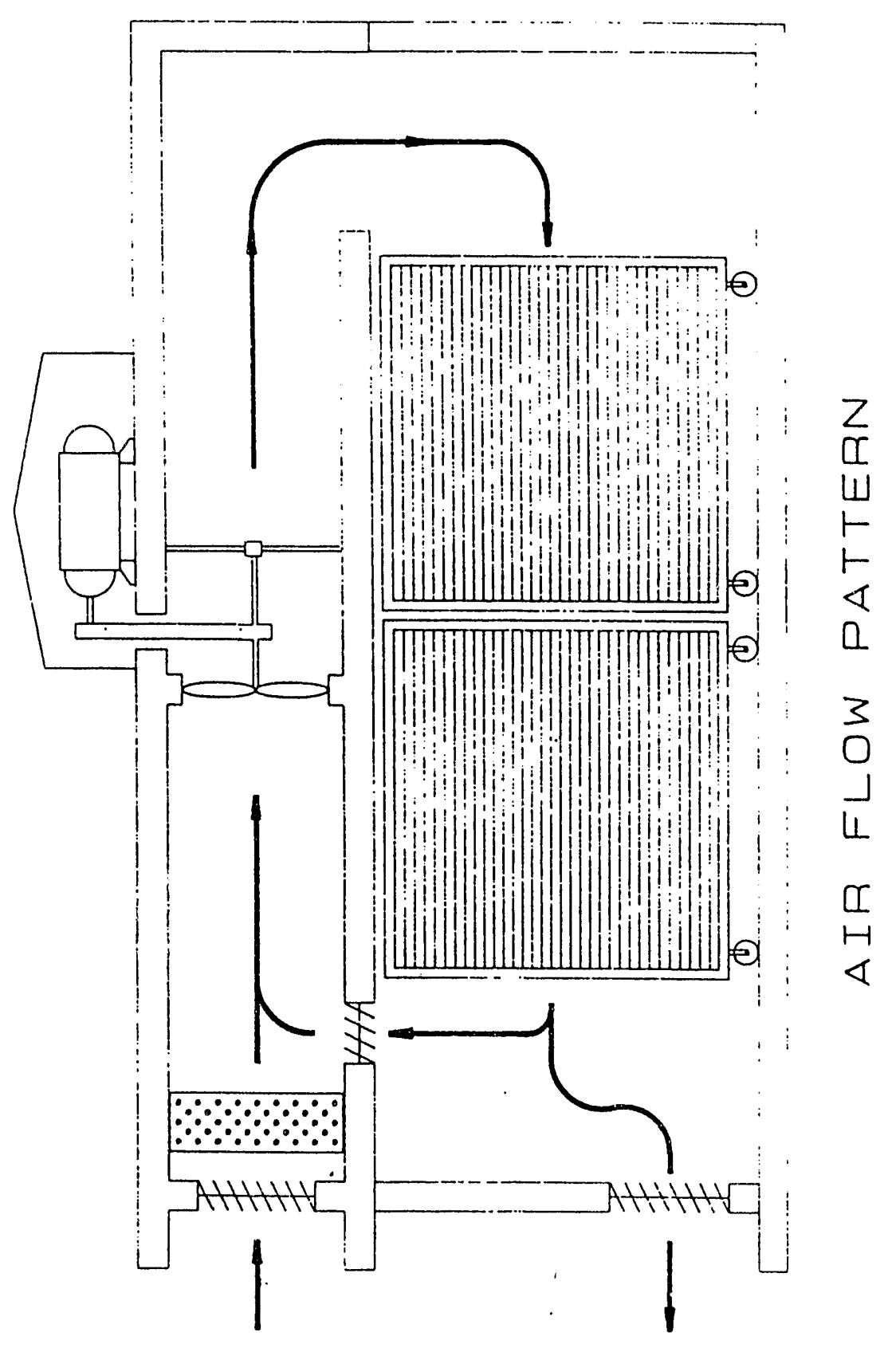




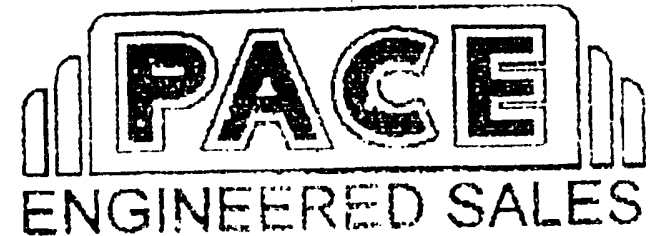

PACE Engineered Sades 9460 S. LE. Lumffild

Clackanias, Oregon 59015

Ptwors (50, $65 \%-71 \%$

Fax (503) 852-7195

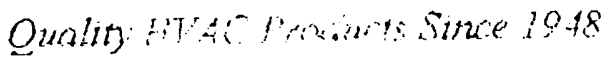

Budget Pricing

To. John Lund

Re. Fan Selextion'pricing, Coil pricing

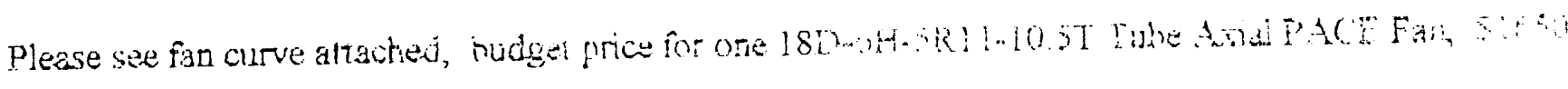

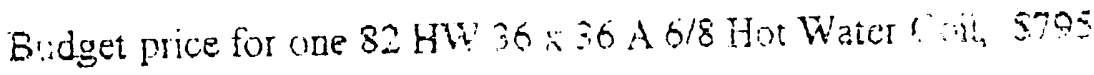

please give me a call if yoli have ang questions

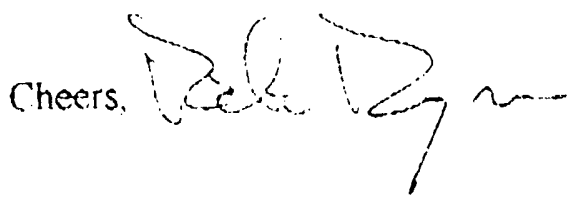

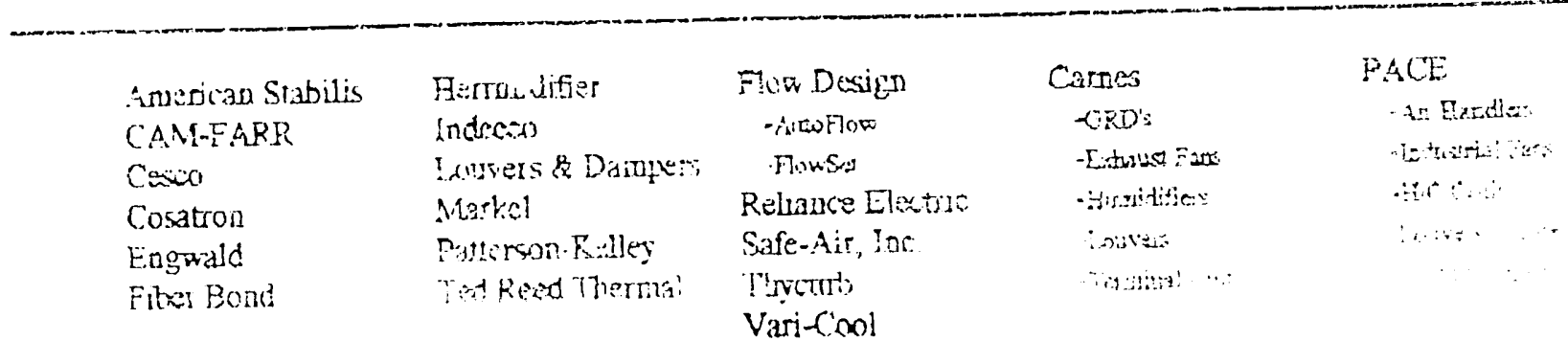




$$
\begin{aligned}
& B-F-O-D \text { \& } M C-D-L-U-N-G \quad F-A-C-E \text { C C-M }
\end{aligned}
$$

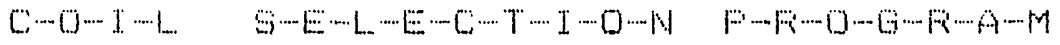

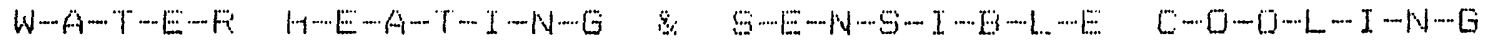

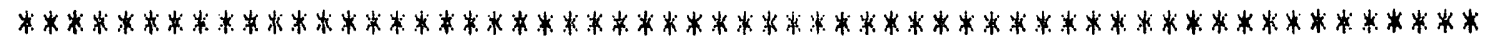

mace: Coil. Model Number-...

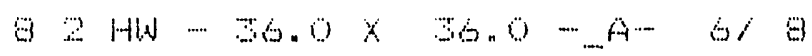

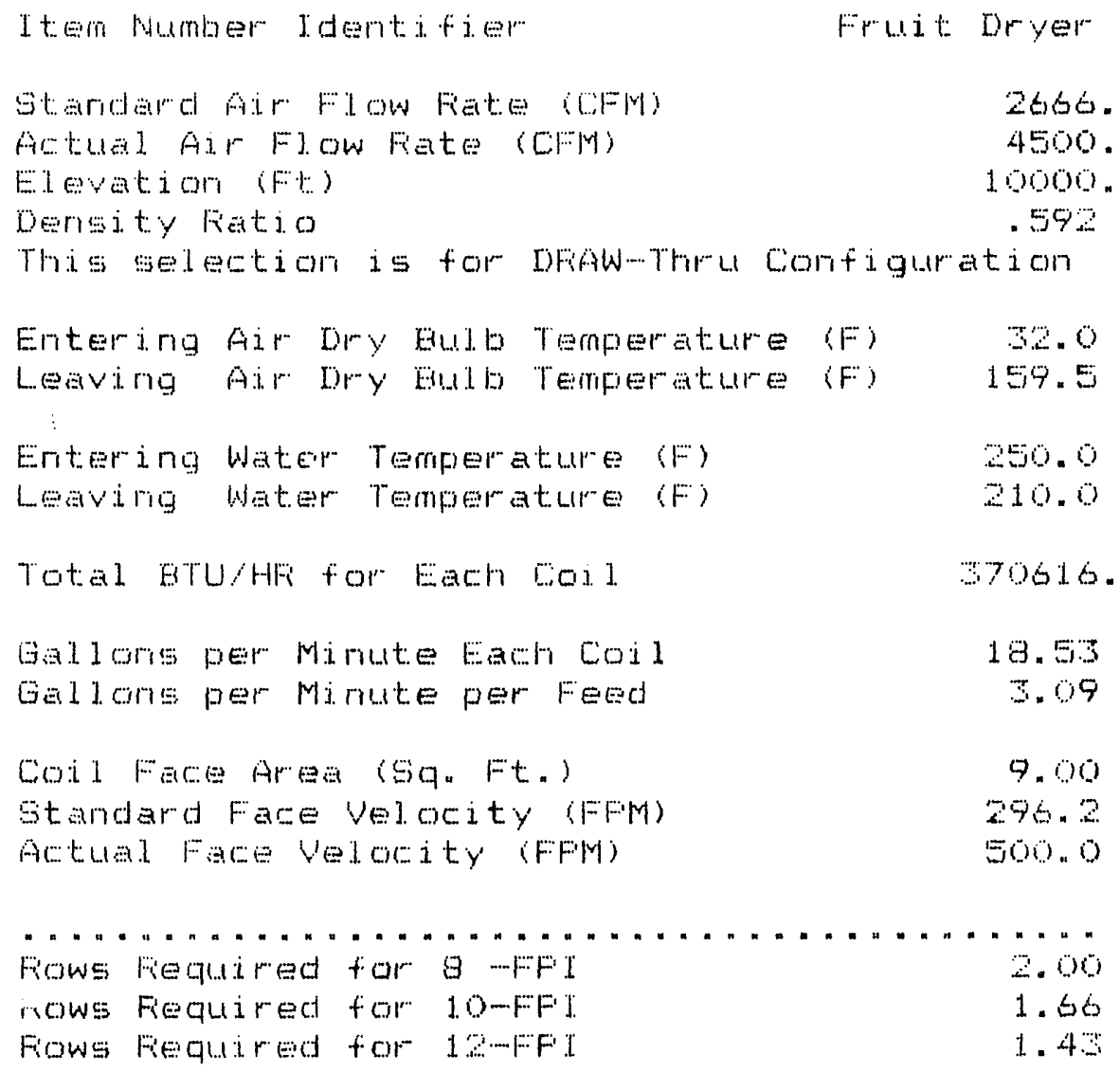

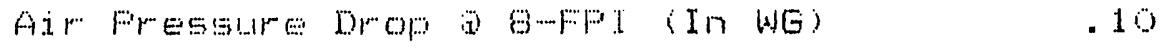

Number of Tulies Fed (circuits) 6

Number of Fasses

Water pressure Drop (Ft. of H2O) 2.82

Comettion $5 i z e(J n)$ 


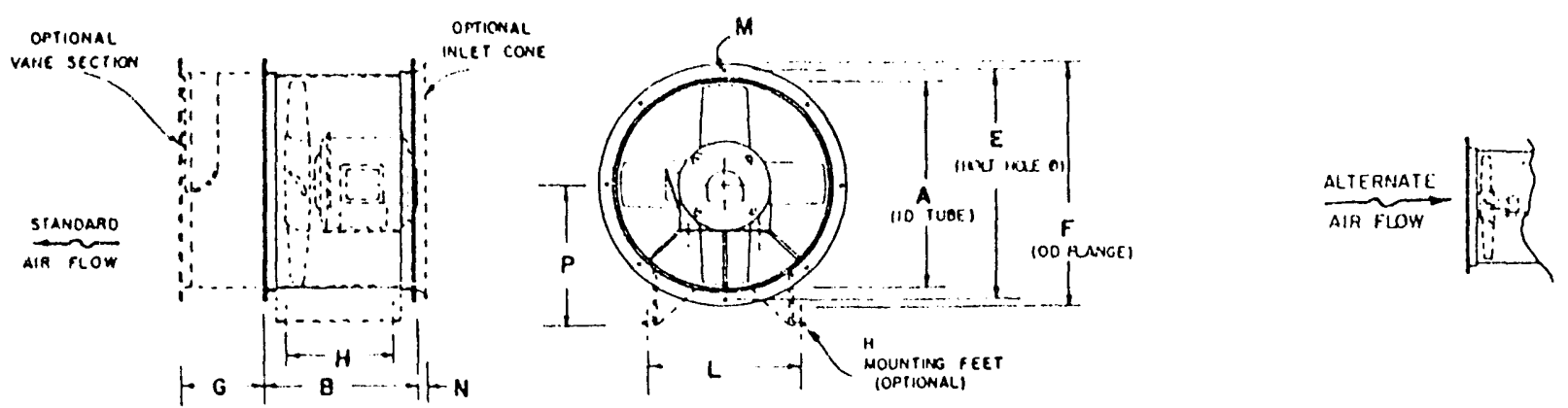

DIRECT DRIVE

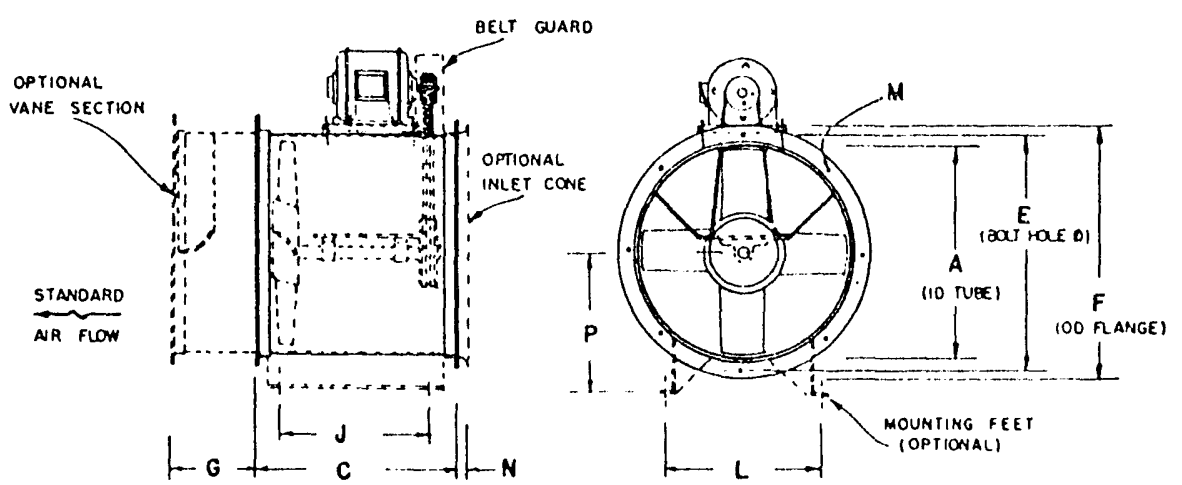

BELT DRIVEN MOTOR EXTERNAL OPEN DRIVE (M.E.O.D.)
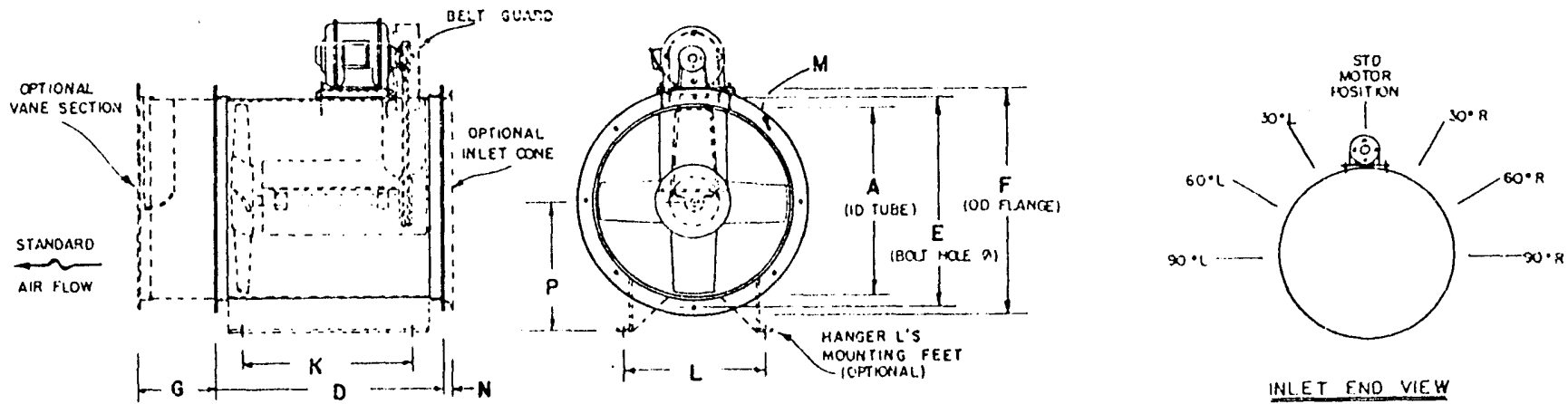

BELT DRIVEN MOTOR EXTERNAL ENCLOSED DRIVE (M.E.E.O.)

INLET END VIEW

\begin{tabular}{|c|c|c|c|c|c|c|c|c|c|c|c|c|c|c|c|c|}
\hline SIZE & A & B & c & 0 & $E$ & $F$ & o & $H$ & $J$ & $k$ & L & & $M$ & $N$ & $P$ & SHAFT \\
\hline 15 & $15 \cdot 388$ & 15 & $25-1 / 2$ & 32 & $16 \cdot 316$ & $17 \cdot 9 / 16$ & 8 & 11 & $21 \cdot 1 / 2$ & 28 & $12-1 / 2$ & 8. & ./ $/ 810$ & 3 & $11 \cdot 34_{4}$ & $1-7 / 6$ \\
\hline 18 & $18-3 / 8$ & 16 & 26 & 32 & $19-916$ & $20-M / 5$ & $8 . v 2$ & 12 & 22 & 28 & $14-V 2$ & 8. & $3 \times 18^{\prime \prime} 0$ & 3 & $13 \cdot 2 \cdot 3$ & $1-7 \Lambda 6$ \\
\hline 21 & $21-3 / 8$ & 19 & $27-1 / 2$ & 32 & $23-1 / 16$ & $24-3 / 16$ & 9 & 14 & $22 \cdot 1 / 2$ & 27 & $16 \cdot 34$ & $8-$ & $1 / 2^{n} 0$ & 3 & $1 \cdot ;-7,4 ;$ & $1.7 / 66$ \\
\hline 24 & $24-3 / 8$ & 19 & 28 & 32 & $26-v 8$ & $27-5 / 8$ & $9 \cdot 1 / 2$ & in & 23 & 27 & 19 & $8-$ & $v 2 " 0$ & 3 & 10.010 & $1-7 / 6$ \\
\hline 27 & $27 \cdot 3 / 8$ & 20 & $28-\sqrt{2}$ & 32 & $291 / 8$ & $30-58$ & 10 & 15 & $23-12$ & 27 & 21 & 8 & $v 2^{\circ} 0$ & 3 & $17-13$ & $1.7 / 6$ \\
\hline 30 & $30-3 / 8$ & 23 & 29 & 32 & $32-1 / 8$ & $33-5.3$ & $D \cdot \sqrt{2}$ & 18 & 24 & 27 & $23 \cdot 6$ & 8. & $v z^{*} 0$ & 4 & (2) & $1-7 / 6$ \\
\hline 32 & $32 \cdot 310$ & 23 & $23 \cdot 12$ & $3 ?$ & $34-V B$ & 35.218 & $10-\sqrt{2}$ & 18 & $24 \cdot \sqrt{2}$ & 27 & $2 a-1 / 2$ & a. & $1 / 2 " \varnothing$ & 4 & $21 * r$ & $1 \cdot 7 n 6$ \\
\hline 34 & $34-3 / 8$ & 23 & $30-1 / 2$ & 41 & $36-v 8$ & $37-5 / 8$ & 11 & 18 & $25-\sqrt{2}$ & 36 & 25 & 8. & $v 2^{\prime \prime} b$ & 4 & 22516 & $1-1100$ \\
\hline 36 & $36-3 / 8$ & 27 & 32 & 41 & $38 \cdot 3$ & $39 \cdot 3 / 4$ & $11-\sqrt{2}$ & 22 & 27 & 36 & $27 \cdot 1 / 2$ & 16 & $\sqrt{2} 2^{\prime \prime} \theta$ & 4 & $25: 3$ & 1 - Ins \\
\hline 40 & $40-3 / 8$ & 27 & 34 & 51 & $42-34$ & $24-3 / 4$ & 12 & 21 & 28 & 45 & $30 \cdot 2 A$ & in & $1 e^{*} 0$ & 4 & ביתמצ'ה & 1-1:10 \\
\hline 44 & $44-38$ & 29 & $34 \cdot 1 / 2$ & 51 & $46 \cdot 3 / 4$ & $38 \cdot 34$ & $12-1 / 2$ & 23 & $28-\sqrt{2}$ & 45 & $33 \mathrm{~kg}$ & 16 & V2" 0 & 5 & 29.88 & $1 \cdot 1 \cdot n 6$ \\
\hline 48 & $48 \cdot 62$ & 29 & 35 & 51 & $50-7 / 8$ & $52 \cdot 78$ & 13 & 23 & 29 & 45 & 36 & 16 & $V 2^{*} \theta$ & 5 & 302 & $1 \cdot 1 \leqslant / 16$ \\
\hline 54 & $54-1 / ?$ & 31 & 37 & 39 & $57-378$ & $59 \cdot 1 / 3$ & 14 & 24 & $3 n$ & 51 & 40 & 16 & $\sqrt{ } 2^{\prime \prime}$ & 5 & siacs & 1 isks \\
\hline$\in \mathcal{C}$ & $\omega 0-1 / 2$ & 3.3 & 38 & $G 4$ & $63-5 / 88$ & $65-78$ & 15 & 25 & 31 & $5 /$ & $m: 2 ?$ & if & vi" : & $s$ & $\therefore r^{\prime}$ & $? \cdot 1 / 6$ \\
\hline Eक & $66 \cdot \sqrt{2}$ & & 39 & 64 & $69-3 / 3$ & $71 \cdot 7 / 8$ & 16 & & 32 & $5 !$ & 9 & ic & י & ' & 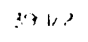 & 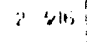 \\
\hline 72 & $72 \cdot 1 / 2$ & & 10 & 0.4 & $75 \cdot 3 / 4$ & $r \cdot 7 / 8$ & 17 & & $3:$ & $\because i$ & $\because \mu$ & if, & $\therefore{ }^{\prime} \cdot$ & $\because$ & 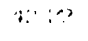 & $\therefore \quad B$ \\
\hline 84 & $84 \cdot 1 / 2$ & & H. & 233 & $87 \cdot 3 / 4$ & $[3]-113]$ & $18-1 / 2$ & & sivi & 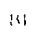 & י & .9 & $\because$, & 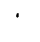 & $\therefore \cdots$ & $\therefore i$ \\
\hline
\end{tabular}




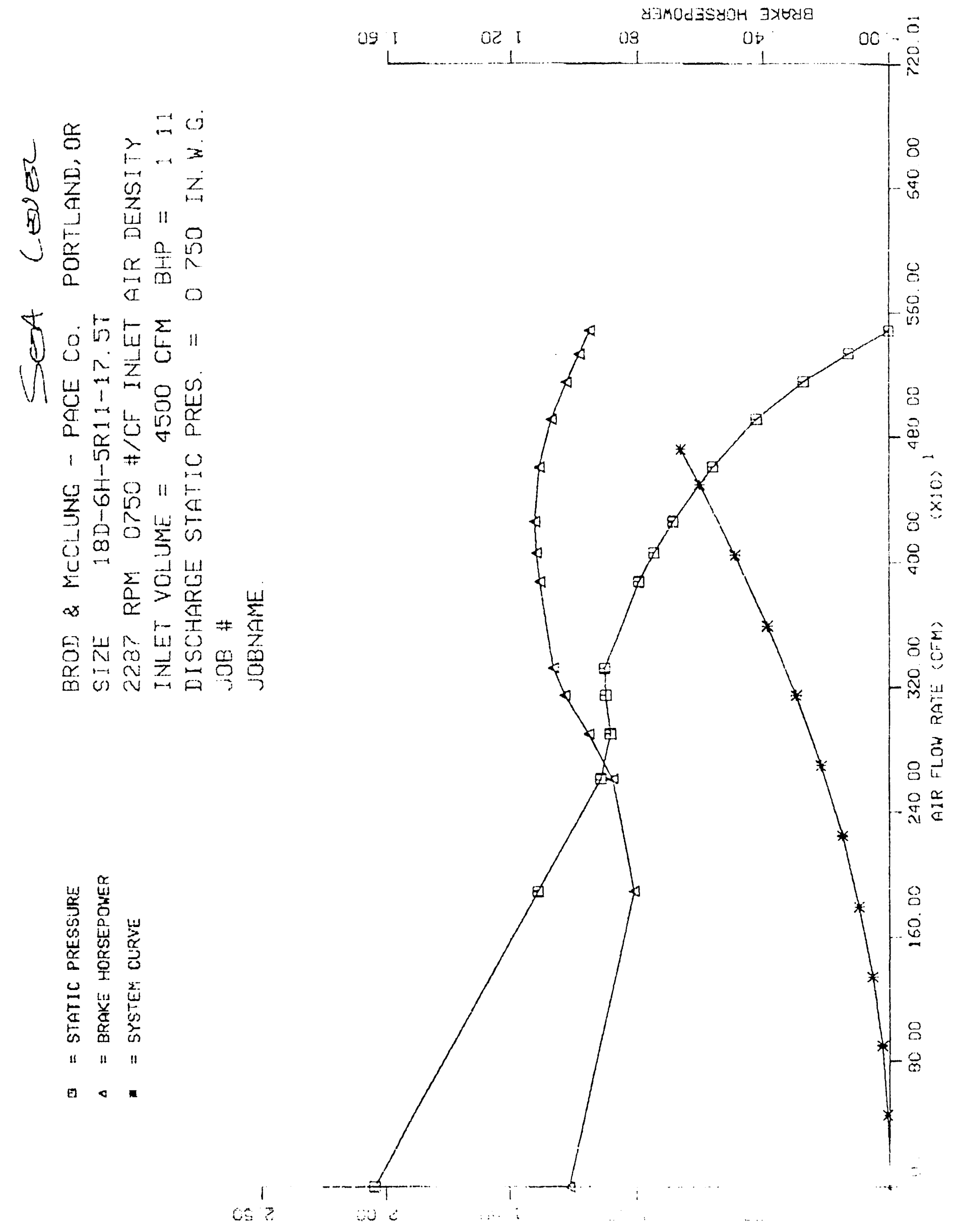




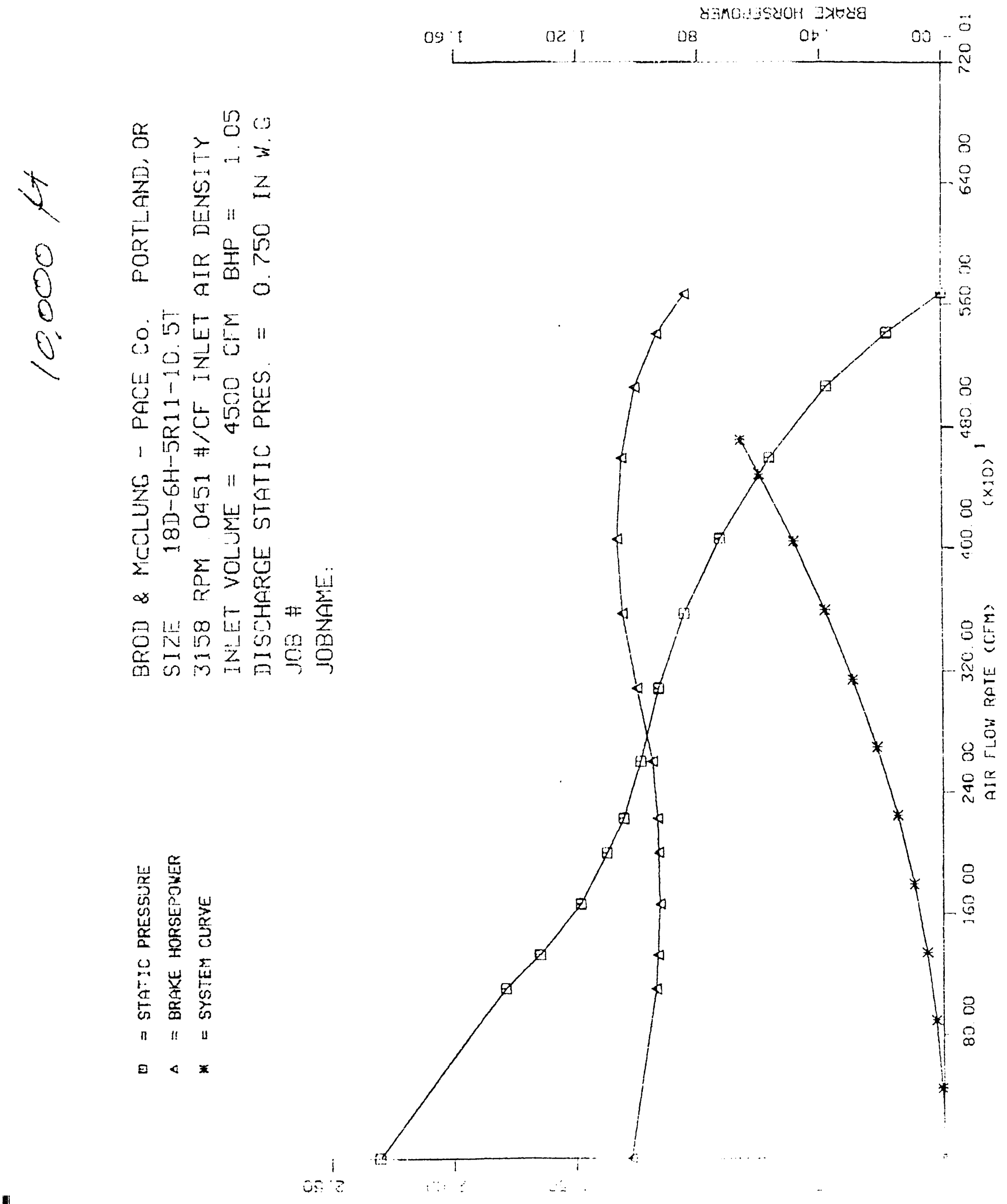


DRYING FRUIT AT THE LOS AZUFRES GEOTHERMAL FIELD

\section{1.- SCOPE OF THE PROJECT}

Comision Federal de Electricidad (CFE) has a Division in charge of the exploration of a geothermal reservoir located in Los Azufres, State of Michoacan.

At present CFE is only using the steam of the wells and rejecting the hot water that comes off associated with the steam.

CFE is interested in promoting the use of the hot water in industries with high consumption of heat. So far we have installed a chamber for drying lumber (wood) with very good results. Several local industrials are interested in constructing their own in Los Azufres and to buy the heat from CFE. We also construted a green house to grow flowers in winter and produce gladiolous bulbs.

Since the region of Los Azufres is mainly a fruit producer (peaches, pears, apple, guava, etc...) we have plans to instal a small "Fruit dryier" for demosfration purpose. We are confident that if we succed in showing the feasibility to dry fruit with geothermal steam, we will have a big demand of heat for big drying factories.

In this report we present the basic information of the field, the heat and the fruits, expecting to receive a proposal with the minimun size of a drying plant, for demostration purpose, having in mind that CFE will promote this industry for wide application in Michoacan State. 


\section{2. - GEOGRAPHICAL}

The Los Azufres geothermal field is located in the Michoacan State at the southwest of the Mexican Republic (Fig. 1). The most important city of Michoacan is Morelia, which is located approximately $80 \mathrm{Km}$ away from Los Azufres (Fig. 2). The city population is around $1,000,000$ inhabitants.

The distance between Morelia and Mexico City is approximately 300 $\mathrm{Km}$. Comunication between this two cities is wide, there are three daily flights and the road coilditions are excelent. Going by car it takes approximately 4 hours.

\section{3. - ATMOSPHERIC CONDITIONS}

Average conditions from 1983 to 1990.

$\begin{array}{lcc}\text { Atmospheric pressure } & 0.73 & \mathrm{bar} \\ \text { Maximum temperature } & 31 & { }^{\circ} \mathrm{C} \\ \text { Minimum temperature } & -4 & { }^{\circ} \mathrm{C} \\ \text { Mean anual temperature } & 12 & { }^{\circ} \mathrm{C} \\ \text { Anual precipitacion } & 1,171 & \mathrm{~mm} \\ \text { Relative Humidity (anual mean) } & 63 & \% \\ \text { Mean wind speed } & 2.2 & \mathrm{~m} / \mathrm{s}\end{array}$

Figs. 4 and 5 show the dry bulb temperature and the relative humidity evolution along the year. 


\section{4.- 8TEAM AND BRINE PRODUCTION}

The field has 63 geothermal wells at an average depth of $2,100 \mathrm{~m}$ (Fig. 3). The total steam production is $1,550 \mathrm{t} / \mathrm{h}$ with a noncondensible gases content of $3 \%$ by weight, which are composed of $97 \% \mathrm{CO}_{2}$ and $3 \& \mathrm{H}_{2} \mathrm{~S}$. The field brine production is $1,600 \mathrm{t} / \mathrm{h}$ at a separation temperature of $170^{\circ} \mathrm{C}$.

The brine production by well is approximately $50 \mathrm{t} / \mathrm{h}$.

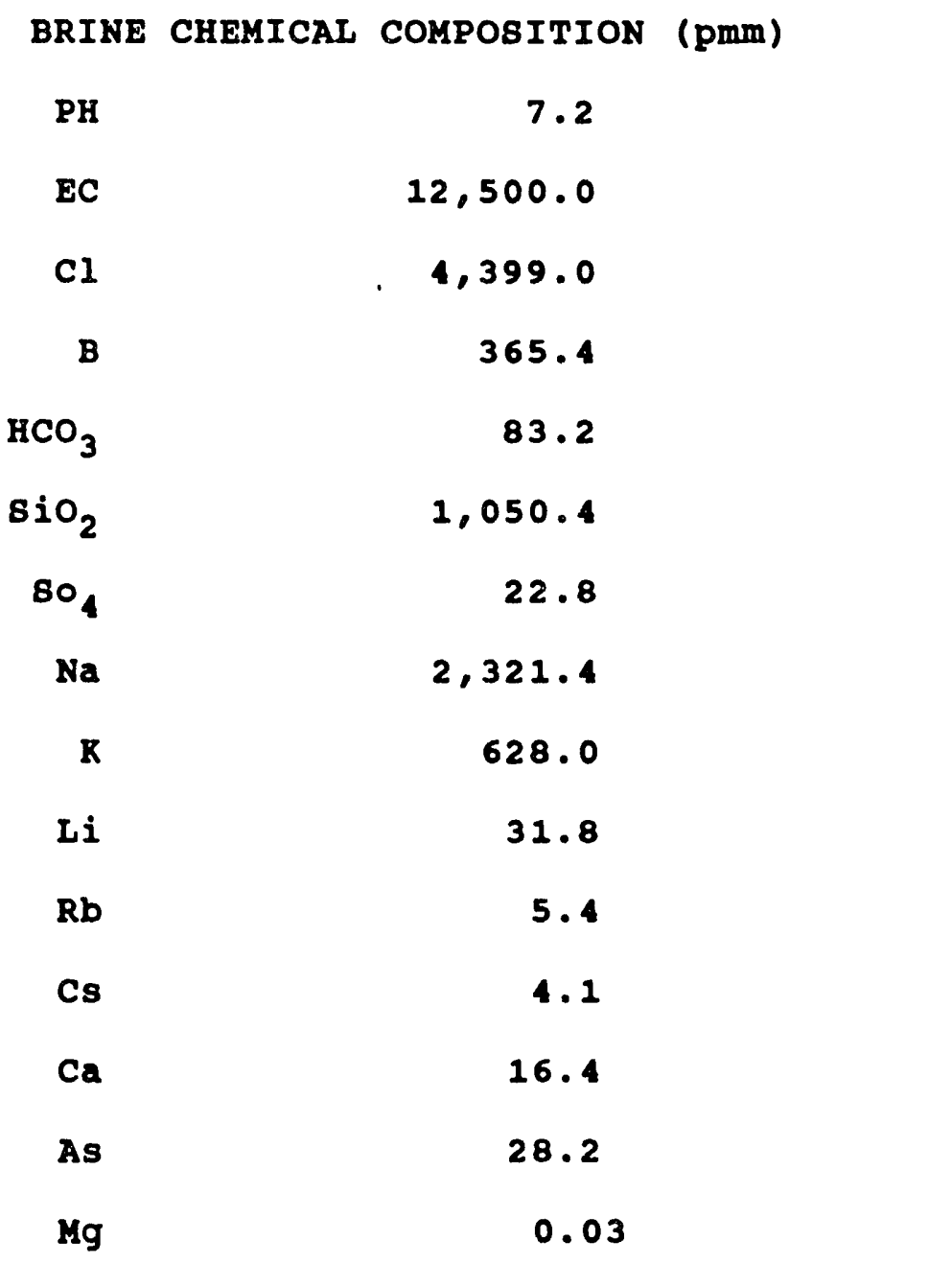




\section{5.- FRUIT TO DRY}

At present, the anual fruit production of the area are the following:

\begin{tabular}{lr} 
& \multicolumn{1}{c}{ Kg/year } \\
- Pear & $15,000,000$ \\
- Peach & $1,350,000$ \\
- Guava & 900,000 \\
- Apple & 140,000 \\
- Prune & $5,000,000$
\end{tabular}

According with recent studies, drying necesities in some cases are estimated in $40 \%$ of the anual production. 


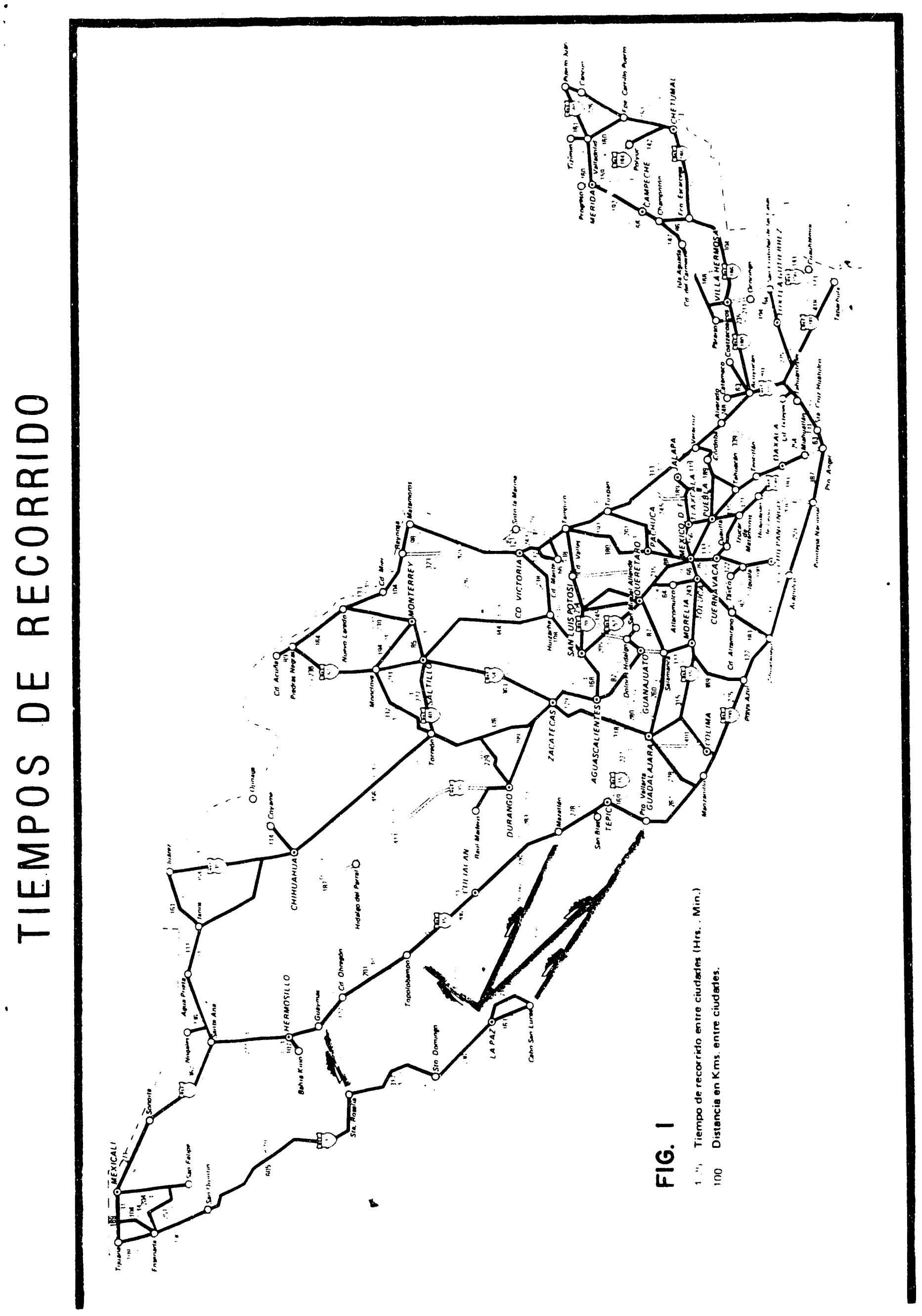




\section{FIG. 2. LOCALIZACION DEL CAMPO GEOTERMICO DE LOS AZUFRES, MICH.}

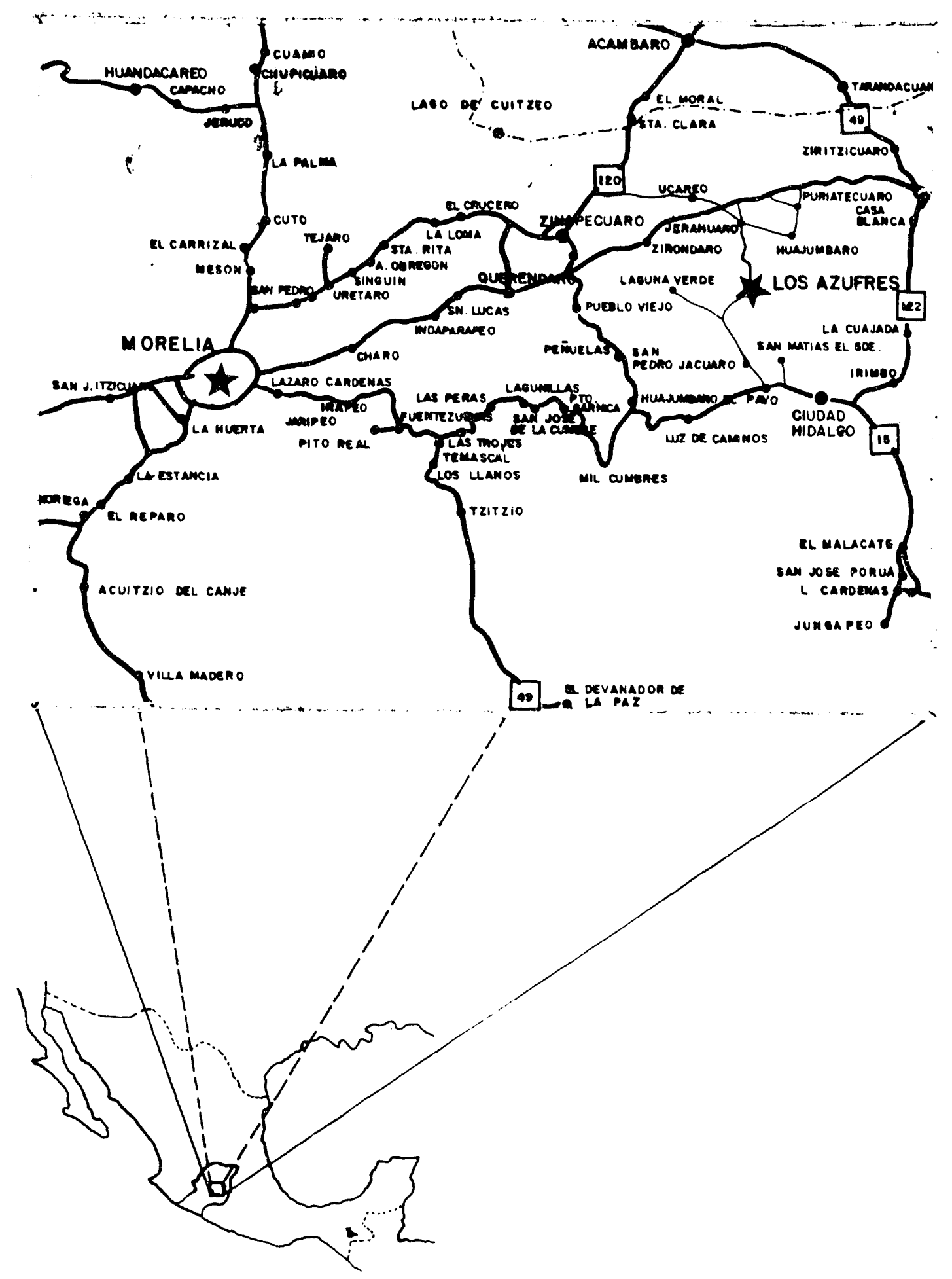




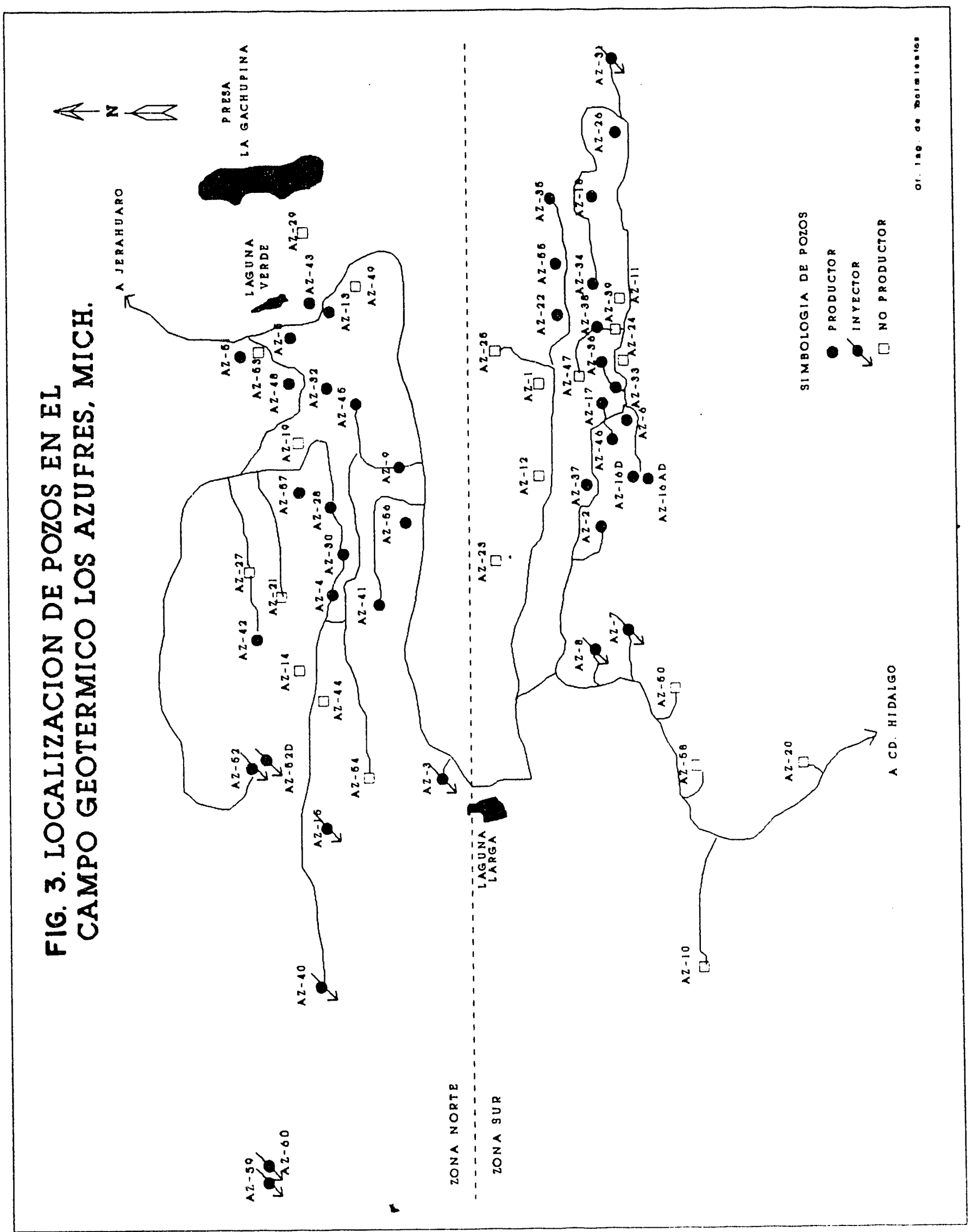




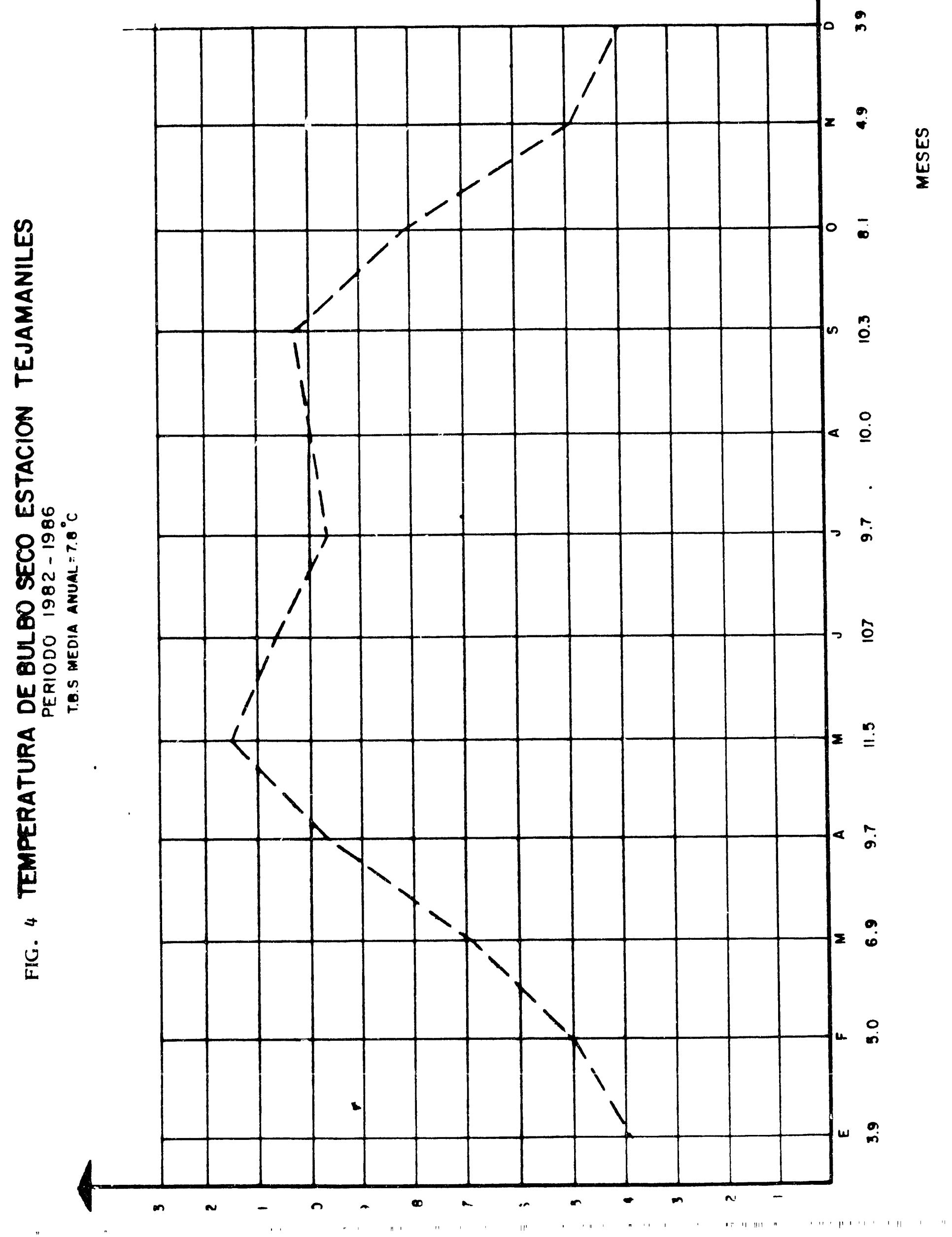



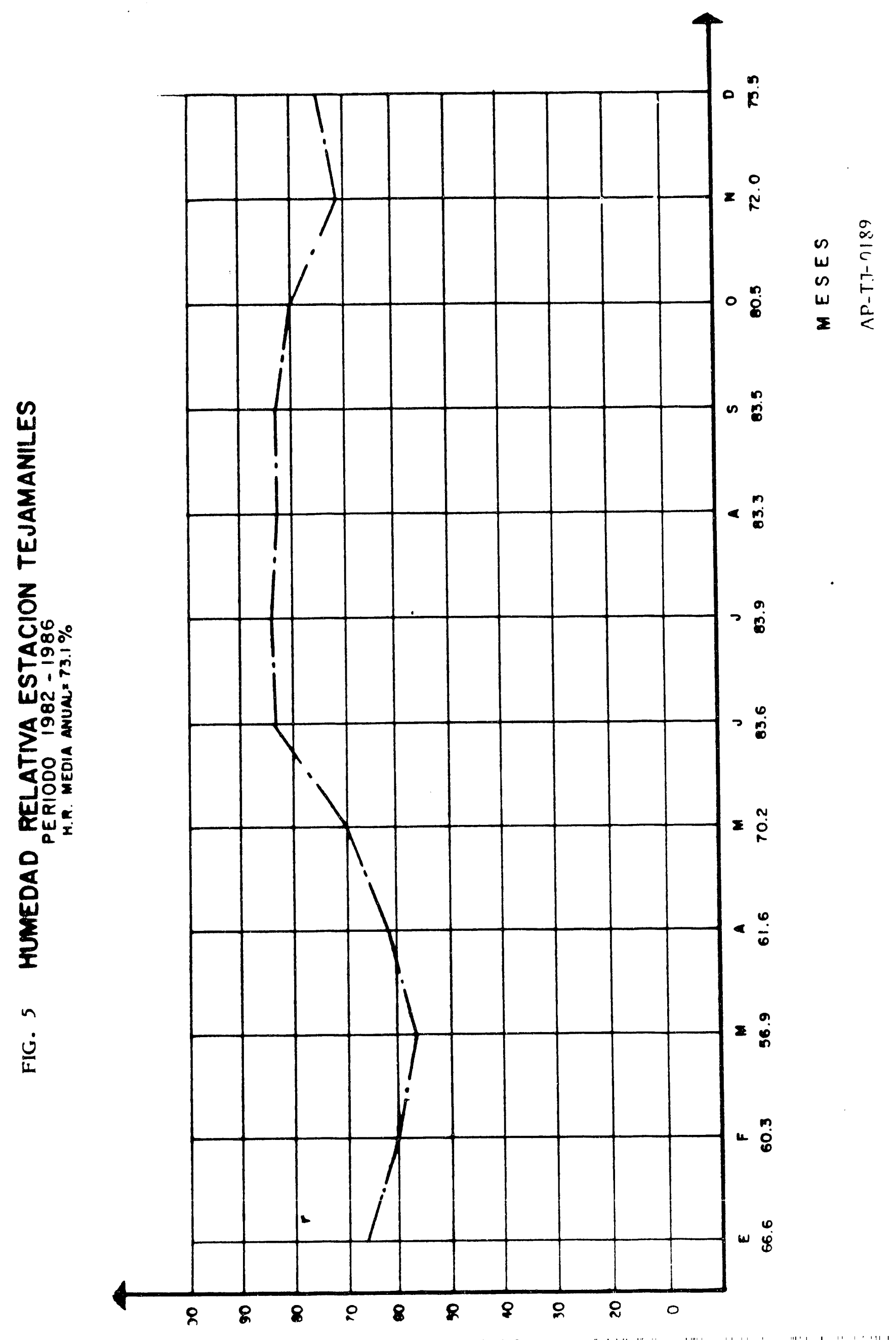
COOPERATIVE EXTENSION

UNIVERSTTY OF CALIFORNIA
Agricultural Engineering Ext.

Davis, CA 95616

Phone: (916) 752-6167

Fax No. (916) 752-2640

Date

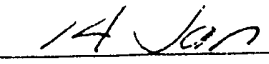

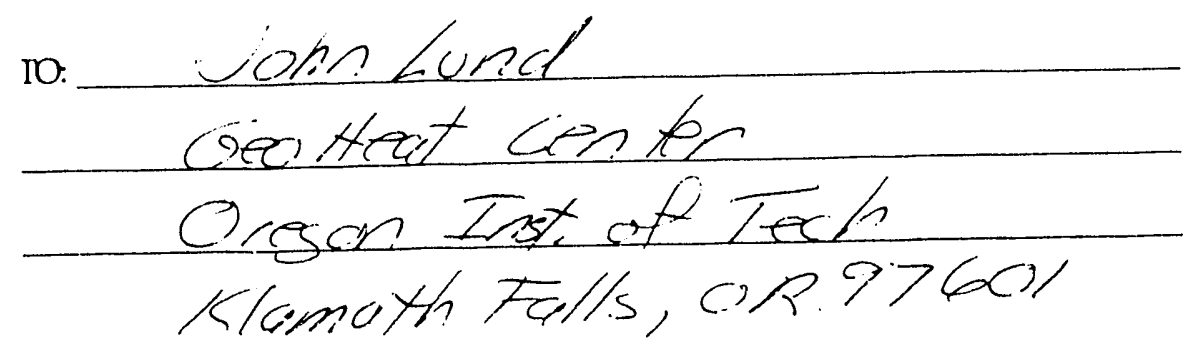

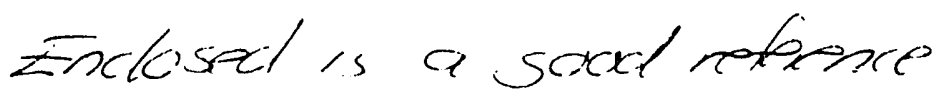

on firit alnjing (out of print)

"Eruit Dehydration"

1. "Principles and Equipment" by R. L. Perry, E. M. Mrak, H. J. Phaff, G. L. Marsh, and C. D. Fisher, California Agriculture Experiment Station, Bulletin 698, December 1946.*

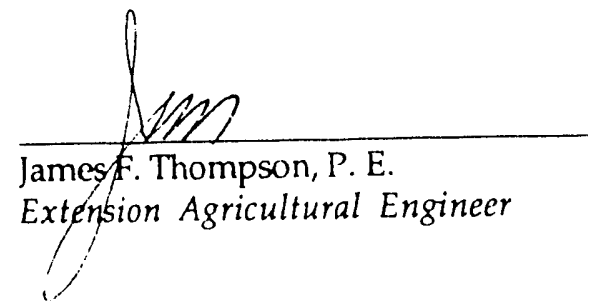

University of California and the United States

Department of Agriculture Cooperating

* Available in the Geo-Heat Center library. 

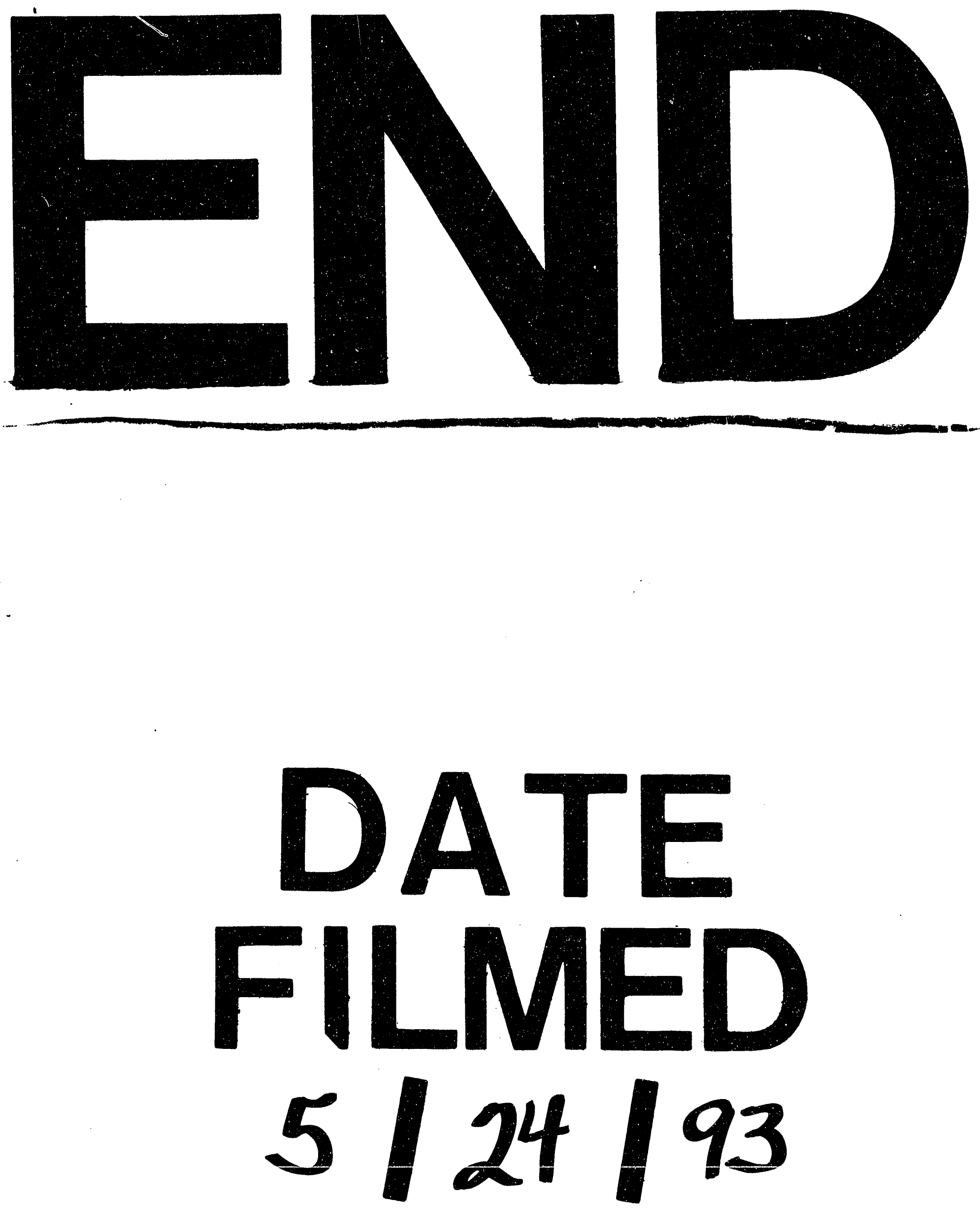

93 


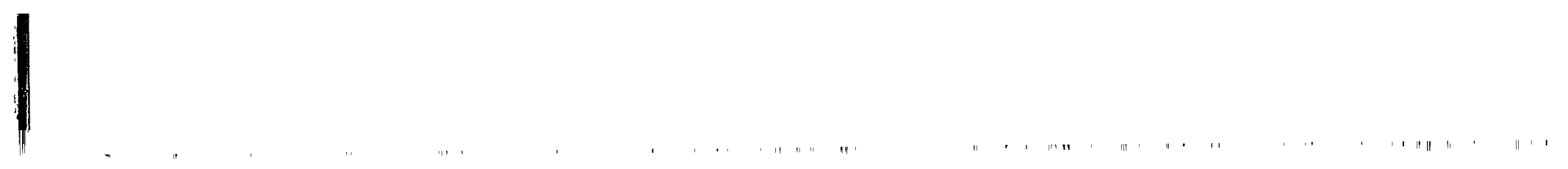

